\title{
Effects of Administration of Tramadol Hydrochloride on the Histological Structure of the Liver and the Possible Protective Role of Curcumin in Adult Albino Rat
}

\author{
DORREIA A.M. ZAGHLOL, M.D.*; SALWA M. OUIES, M.D.** and NAGLAA H. ABBAS, M.Sc.** \\ The Department of Human Anatomy \& Embryology, Faculty of Medicine, Assiut* and Sohag** Universities
}

\begin{abstract}
Background: Tramadol hydrochloride is a synthetic opioid. It is a centrally acting analgesic drug widely used in the treatment of pain. Curcumin is a medicinal plant extensively used as a home remedy for various diseases. It is shown to have anti-inflammatory and antioxidant properties.
\end{abstract}

Aim of the Work: To detect the toxic effects of the tramadol on the histological structure of the liver tissue and to study the possible protective role of curcumin against its toxic effects.

Material and Methods: 30 adult albino rats were used. The animals were divided into three groups each of them consists of 10 rats: Group I: (Control group): Animals were given normal saline orally by intragastric tube in a dose of $25 \mathrm{ml} / \mathrm{kg}$ every day for one month. Group (II): Animals were given Tramadol Hydrochloride in a dose of $25 \mathrm{mg} / \mathrm{kg}$ body weight orally by intragastric tube every day for one month. Group (III): Animals were given Tramadol Hydrochloride in a dose of $25 \mathrm{mg} / \mathrm{kg}$ body weight and curcumin solution in a dose of $80 \mathrm{mg} / \mathrm{kg}$ body weight orally by intragastric tube every day for one month. At the end of the experiment, the rats were anaesthetized by ether then perfused with saline then with the appropriate fixator, the liver was obtained and subjected to light and transmission electron microscopic studies.

Results: Tramadol caused dilatation in the central vein, blood sinusoids and degeneration of hepatocytes at light and electron microscopic examination and statistical studies. Administration of curcumin could improve these effects.

Conclusion: Tramadol caused loss of normal pattern of hepatic tissue with degeneration of some hepatocytes. Curcumin improved the picture of the liver tissue and decreased degeneration in hepatocytes.

Key Words: Liver - Tramadol - Curcumin

Correspondence to: Dr. Dorreia A.M. Zaghlol, The Department of Human Anatomy \& Embryology, Faculty of Medicine, Assiut University

\section{Introduction}

TRAMADOL Hydrochloride ( $\mathrm{TrHC}$ ) is a synthetic analgesic drug which showing opioid and nonopioid properties, it acts mainly on the Central Nervous System (CNS). This drug is structurally related to codeine and morphine, but is 6000-times less potent than morphine and 10-times less potent than codeine [1]

Tramadol acts on t-opioid and k-opioid receptors with low affinity as an opioid agonist, it also affects monoamine receptor systems by blocking the Norepinephrine (NE) and serotonin (5-HT) reuptake which are responsible for the inhibition of pain transmission in the spinal cord [2].

Tramadol is extensively metabolized in the liver to O-desmethyltramadol (M1) and N-desmethyltramadol (M2), being the main phase-1 metabolites. These are further metabolized to three secondary metabolites which finally conjugate with glucuronic acid and sulfate before excretion in urine. The route of elimination almost totally involves the kidneys [3]

Tramadol relieves moderate to severe postoperative pain [4]. It is also used for the treatment of premature ejaculation and was found to be effective, safe and tolerable, with minimal undesirable effects [5]. Tramadol is used in the treatment of gastrointestinal disorders e.g. the irritable bowel syndrome in combination with other drugs e.g. antiemetics, antispasmodics [6].

Curcumin, curcuma longa, (turmeric or curcu$\mathrm{ma}$ ) is a rhizomatus monocotyledonous perennial herbaceous plant member of the ginger family (Zingiberaceae), endemic and prevalent in tropical 
and subtropical regions including India, China and South East Asia [7]. Curcumin is considered a drug effective for various respiratory conditions (asthma, bronchial hyperactivity, and allergy) as well as for other disorders including anorexia, coryza, cough, hepatic diseases, and sinusitis [8].

Curcumin has the ability to inhibit proinflammatory transcription factors such as Tumor Necrosis Factor (TNF) and Interleukin (IL-6) [9] . It acts as antioxidant by increasing liver Glutathione Peroxidase (GSH-Px) and catalase activities [10].

\section{Aim of the work:}

The aim of the study is to detect the effects of tramadol on the histological structure of the hepatic tissue in male albino rats and to know whether curcumin has a protective role or not against tramadol effects by histological and ultrastructural study.

\section{Material and Methods}

\section{Animals used:}

The research was done in 2016. A total number of 30 adult male albino rats (average weight 200$250 \mathrm{gm}$ ) were brought from the Animal House of Sohag Faculty of Science. They were reared underthe standard conditions of feeding, light-dark ratio and temperature.

Tramadol hydrochloride was obtained in the form of commercially packed tablets (Tamol-X) from Royal National Pharmaceutical Company. Each tablet contains $225 \mathrm{mg}$ of tramadol hydrochloride. The tablets ( 8 and $1 / 3$ tablets) were grinded and dissolved in $500 \mathrm{ml}$ saline. Hence each rat received $6.25 \mathrm{mg}$ of the drug in $1.6 \mathrm{ml}$ of the prepared solution.

Curcumin was obtained in powder form from El-Gomhouria Company. 3 grams were dissolved in $300 \mathrm{ml}$ (saline and Acacia gum). Hence each rat received $20 \mathrm{mg}$ of curcumin in $2 \mathrm{ml}$ of the prepared solution.

The animals were divided into 3 groups; each of them consists of 10 rats.

Group (I) [control group]:Animals were given normal saline orally by intragastric tube in a dose of $25 \mathrm{ml} / \mathrm{kg}$ body weight every day for one month.

Group (II) [tramadol treated group]:Animals were given Tramadol Hydrochloride in a dose of $25 \mathrm{mg} / \mathrm{kg}$ body weight [11] orally by intragastric tube every day for one month.
Group (III) [tramadol-curcumin treated group]: Animals were given Tramadol Hydrochloride in a dose of $25 \mathrm{mg} / \mathrm{kg}$ body weight and curcumin solution in a dose of $80 \mathrm{mg} / \mathrm{kg}$ body weight orally by intragastric every day for one month [12]

At the end of the experiment, the rats were anaesthetized by ether then perfused with saline then with the appropriate fixator (Formalin 10\%). The abdomens were opened and the livers were extracted from the control and treated animals for light and transmission electron microscopic studies.

For light microscopic study: Specimens were fixed in $10 \%$ neutral buffered formalin and processed for light microscopic study to get paraffin sections of 6 ickness. Sections were stained with Haematoxylin and Eosin (H \& E) and Masson's Trichrome stain.

For Transmission Electron Microscopic study (TEM): Specimens were cut in small pieces and fixed in $2.5 \%$ glutaraldehyde for 24 hours, washed by sodium cocodylate buffer solution, postfixed in $1 \%$ osmium tetraoxide in sodium cacodylate buffer for two hours, then washed and dehydrated in ascending grades of alcohol, ehanol 30\%, 50\%, $70 \%, 95 \%$. The specimens were embedded in Mollenhauer's Epon-Araldite formulation and the tissue blocks were polymerized in an oven. Blocks were trimmed with a razor blade and cutting was done by a glass knife in KLB ultramicrotome. Semithin sections were stained with Toluidine blue. U1trastructural sections were mounted on copper grids, stained with Uranyl acetate and Lead citrate and were examined by transmission electron microscope (Jeol-1010) in Assiut University.

\section{Morphometric and statistical analysis:}

Estimation of the mean diameter of the central vein and hepatocytes (maximum diameter) (at magnification 400) was done. Measurements were performed in Haematoxylin and Eosin (H \& E) sections, 2-3 sections per animal. In each section five measurements were obtained from five randomly chosen fields using an image analysis system (digimizer version 3.7.2005-2010) medcalc software in the Anatomy Department at Sohag University.

\section{Statistical analysis:}

Statistical analysis of measurements of mean diameters of the central vein and hepatocytes were done using SPSS soft ware Version 16. Variables were represented by mean \pm SD (mean \pm standard deviation of mean). One way ANOVA was used to 
compare the means of these variables between different groups. Finally the significance was considered according to the level of significance $p$ value as follows:

$-p>0.05$ non significant.

$-p \nmid 0.05$ significant*.

$-p \leq 0.01$ highly significant**.

$-p \leq 0.001(* * *)-$ very high significant difference.

\section{Results}

\section{Group I (control group):}

Histological study:

Light microscopic sections showed the normal architecture of liver. The hepatic lobule consisted of the central vein in the centre of the lobule and plates of hepatocytes radiating from the centre towards the periphery Fig. (1). The hepatocytes appeared polyhedral in shape with centrally located rounded vesicular nuclei. Some hepatocytes were binucleated Fig. (3). The cytoplasm of hepatocytes appeared acidophilic with basophilic granules. Blood sinusoids were observed between hepatocytes and were lined by flat endothelial cells. Blood sinusoids also contained Von Kupffer cells Figs. $(1,2)$. The portal triad appeared at the periphery of the hepatic lobule having a branch of the portal vein, hepatic artery and bile duct Fig. (2). The liver sections revealed thin layer of collagen fibers around the central vein. There were also few collagen fibers around the portal triad forming a common sheath around its elements Figs. $(4,5)$.

\section{Ultrastructural study:}

The hepatocyte appeared with a well defined border and a large rounded centrally located nucleus and with a sharp border and a prominent nucleolus. Large number of mitochondria and rough endoplasmic reticulum appeared in the cytoplasm Fig. (6). The blood sinusoids showed 2 types of cells Von Kupffer and stellate cell. Kupffer cell had a large nucleus surrounded by a thin rim of cytoplasm. There were filtration slits between endothelial cells lining the sinusoid. The sinusoidal surface showed the space of Disse separating the sinusoids from the hepatocyte containing numerous fenestrations between sinusoidal cells. Large hepatic stellate cells appeared in space of Disse between hepatocytes. Stellate cell had a well defined euchromatic nucleus surrounded by a large volume of cytoplasm containing lipid drops Fig. (7).

\section{Group II (tramadol group):}

Histological study:

Light microscopic study in sections of liver after treatment with tramadol showed loss of normal pattern of the liver with marked dilatation in the central vein Fig. (8). Some specimens showed normal central vein but with lymphocytic infiltration around it Fig. (9). Blood sinusoids showed hemorrhage inside them Fig. (8). Some hepatocytes showed vacuolation in the cytoplasm and loss of their nuclei Fig. (11). Other hepatocytes had shrunken and dark stained nuclei. Some von kupffer cells appeared enlarged Fig. (11). In the portal area, there was dilated congested portal vein with mild dilatation in the hepatic artery and bile duct in comparison with control group Fig. (10). Liver sections showed marked increase of collagen fibers around the central vein Fig. (12).

\section{Ultrastructural study:}

Hepatocyte appeared with ill defined border. It had a marked shrunken nucleus with abnormal chromatin pattern. The cytoplasm appeared vacuolated with marked decrease in number of mitochondria and rough endoplasmic reticulum which appeared destructed Fig. (13). In the blood sinusoid, Von Kupffer cell appeared enlarged with heterochromatic nucleus and rarified cytoplasm around it. The space of Disse showed absent fenestrations Fig. (14).

\section{Group III (tramadol-curcumin):}

Histological study:

There was an improvement in the picture of the liver in the form of regular cords of hepatocytes. Mild dilatation in the central vein in some areas was observed Fig. (15). The blood sinusoids were improved Figs. $(15,17)$. Hepatocytes showed mild vacuolation of the cytoplasm with absent nuclei. Other hepatocytes had shrunken nuclei. Some hepatocytes appeared with normal large nuclei and normal cytoplasm. Von kupffer cell appeared enlarged Fig. (17). In the portal area, there were marked dilated congested portal vein with normal hepatic artery and bile duct Fig. (16). Liver sections after addition of curcumin to tramadol showed fine deposition of collagen fibers around the central vein Fig. (18).

\section{Ultrastructural study:}

Hepatocyte appeared with a well defined border. The nucleus was small but with well defined border and prominent nucleolus. Cytoplasm showed some destruction and vacuolation but was filled with mitochondria Fig. (19). The blood sinusoid had a small stellate cell, enlarged Von Kupffer cell. The 
space of Disse showed normal fenestrations Fig. (20).

\section{Morphometric study:}

- Diameter of central vein: (Table 1), Diagram (1):

Mean central vein diameter in Group II (1203.25 pixels) showed a highly significant $(p=0.000)$ increase when compared with Group I (529.20 pixels) and Group III (610.86 pixels).

- Diameter of hepatocyte: (Table 1), Diagram (1):

Mean hepatocyte diameter in Group II (126.05 pixels) showed a highly significant $(p=0.000)$ decrease when compared with Group I (162.26 pixels) and Group III (189.75 pixels).

Table (1): Showing the mean diameter (in pixels) of central vein and Hepatocyte in control and experimental groups.

\begin{tabular}{lcccccc}
\hline Parameters & $\begin{array}{c}\text { Group I } \\
\text { (Control) }\end{array}$ & $\begin{array}{c}\text { Group II } \\
\text { (Tramadol } \\
\text { treated) }\end{array}$ & $\begin{array}{c}\text { Group III } \\
\text { (Tramadol- } \\
\text { Curcumin treated) }\end{array}$ & $\begin{array}{c}\text { P1 } \\
\text { Value }\end{array}$ & $\begin{array}{c}\text { P2 } \\
\text { Value }\end{array}$ & $\begin{array}{c}p \text { - } \\
\text { Value }\end{array}$ \\
\hline Diameter of central vein (Pixels) & 529.20 & 1203.25 & 610.86 & $0.000^{* * *}$ & 0.401 & $0.000^{* * *}$ \\
Diameter of hepatocyte (Pixels) & 162.26 & 126.05 & 189.75 & $0.021^{*}$ & $0.044^{*}$ & $0.000^{* * *}$ \\
\hline
\end{tabular}

P1 value : Comparison between Group I \& Group II. P2 value : Comparison between Group I \& Group III. $p$-value : Comparison between Group I, II \& Group III.

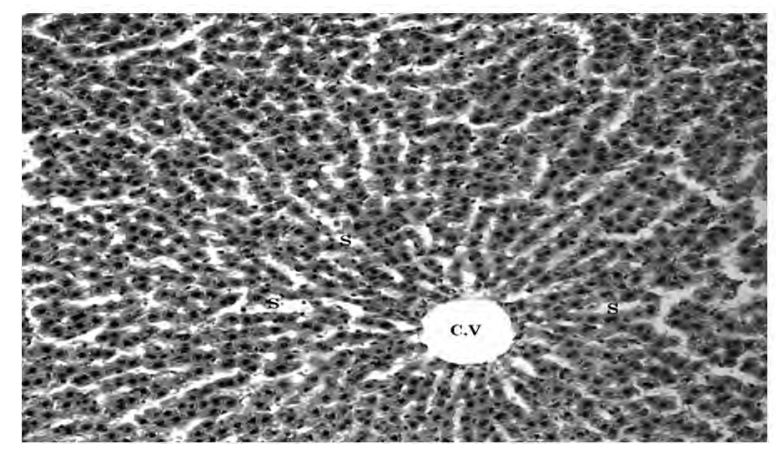

Fig. (1): A photomicrograph of a section of liver of (Group 1) control rat showing; Central Vein (C.V) surrounded by plates of hepatocytes with presence of blood sinuosoids in between (S). (H \& E X200).

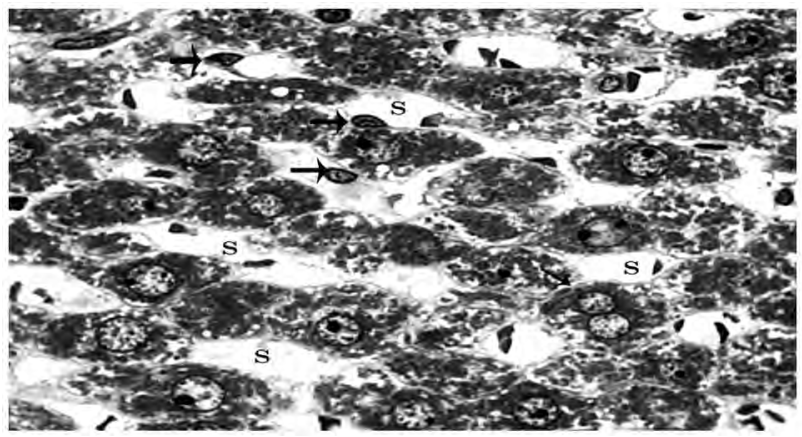

Fig. (3): A photomicrograph of semithin section in liver of (Group 1) control rat showing; cords of hepatocytes with blood Sinusoids (S) are seen between the hepatocytes. Hepatocytes are polyhedral with large centrally located vecicular nuclei. Some hepatocytes are binucleated (thin arrow). The cytoplasm has basophilic granules. Von kupffer cells appeared in sinusoids (thick arrows). (Toluidine blue X1000).
P \& P1 $\leq 0.001(* * *)-{ }^{*}$ Very high significant difference. P1 \& P2 $<0.05(*)-{ }^{*}$ significant. P2 $>0.05$ non significant.

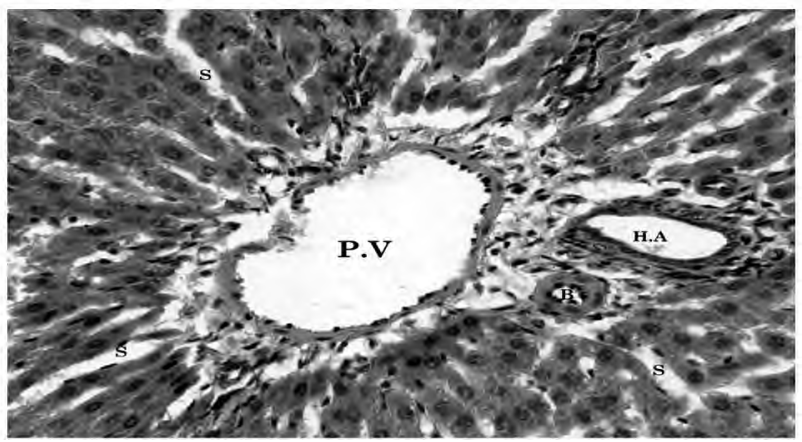

Fig. (2): A photomicrograph of a section of liver of (Group 1) control rat showing; portal triad containing, Portal Vein (P.V), hepatic artery (H.A) and Bile duct (B) surrounded by plates of hepatocytes with presence of blood sinuosoids in between (S). (H \& E X400).

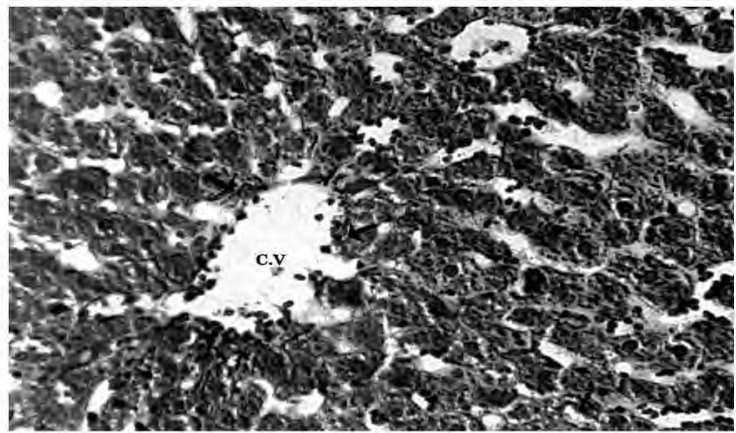

Fig. (4): A photomicrograph of a section of liver of (Group 1) control rat showing; normal distribution of collagen fibers around Central Vein (C.V) (arrows). (Masson's trichrome X400). 


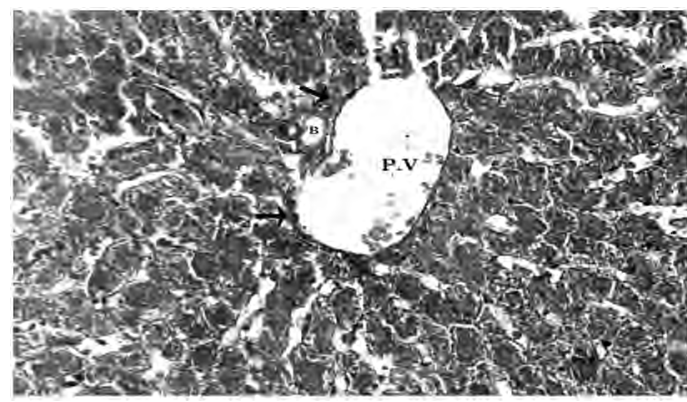

Fig. (5): A photomicrograph of a section of liver of (Group 1) control rat showing; normal distribution of collagen fibers around the portal tract (arrows). (Masson's trichrome $\mathrm{X} 400$ ).

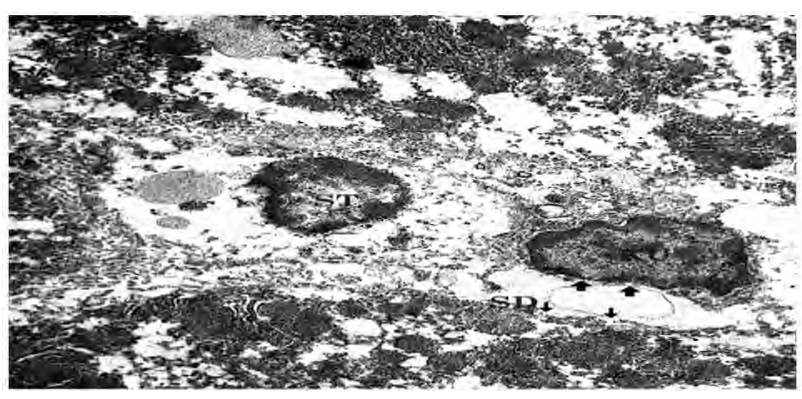

Fig. (7): An electron micrograph of blood sinusoid in liver of (Group 1) control rat showing; stellate cell (ST), Von Kupffer cell (KU) with filtration slits (thick arrows) and Space of Disse (SD) with fenestrations (thin arrows). (X7200).

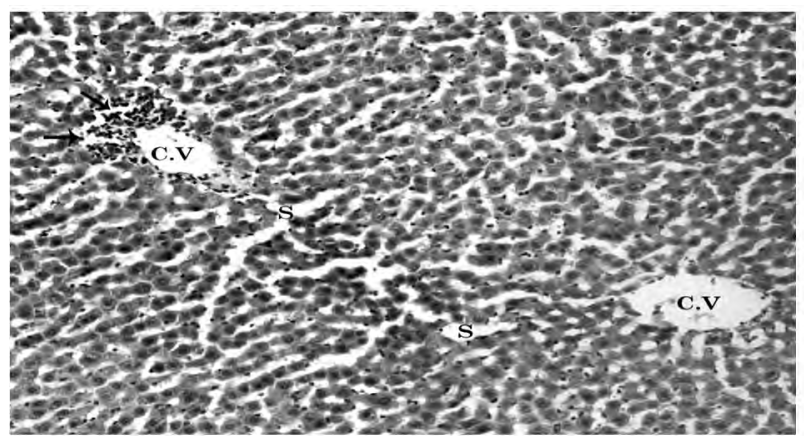

Fig. (9): A photomicrograph of a section of liver of (Group 2) tramadol treated rat showing; normal Central Vein (C.V) and lymphocytic infiltration around central vein (arrows). [Notice: Blood Sinuosoids (S)] (H \& E X200).

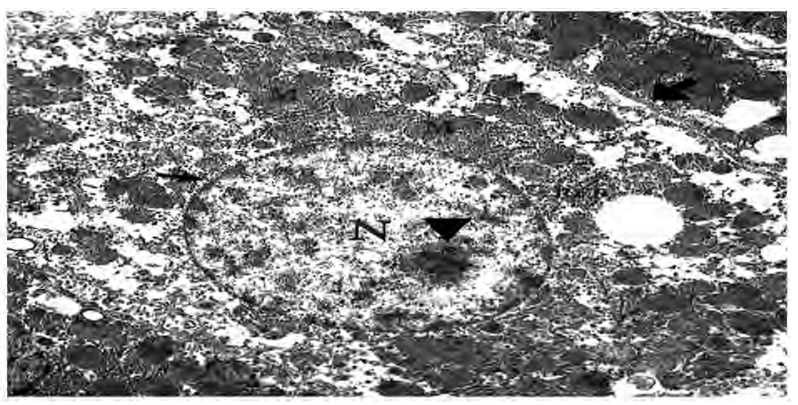

Fig. (6): An electron micrograph of a hepatocyte in liver of (Group 1) control rat showing; well defined cell border (thick arrow), a large rounded centrally located nucleus (N) with nucleolus (arrow head) and well defined border (thin arrow), large number of mitochondria (M) and Rough Endoplasmic Reticulum (RER). (X4800).

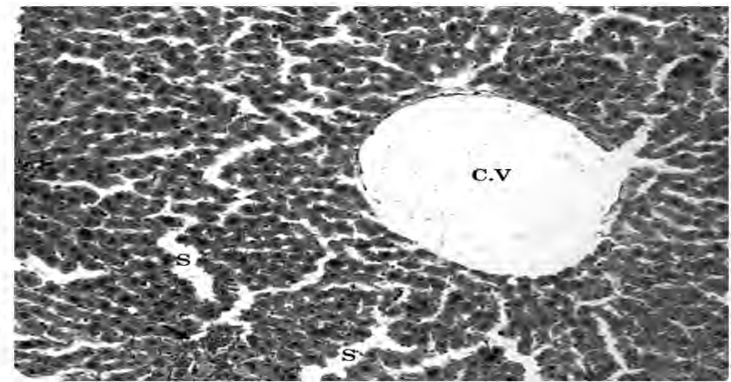

Fig. (8): A photomicrograph of a section of liver of (group 2) tramadol treated rat showing; markedly dilated Central Vein (C.V) and dilatation in blood Sinuosoids (S) with haemorrhage in it (arrow). (H \& E X200).

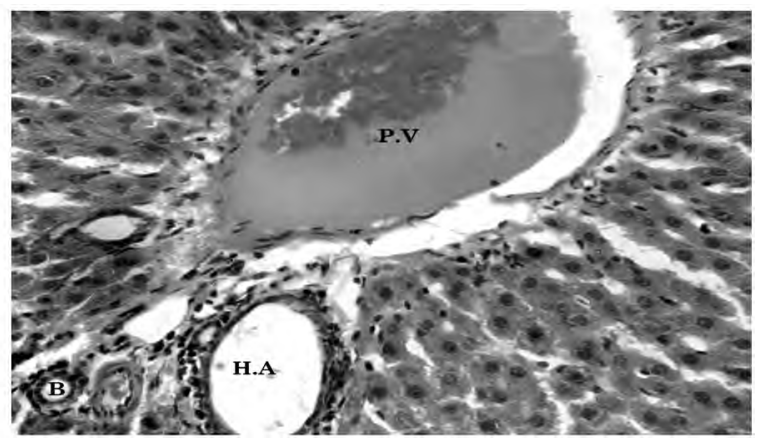

Fig. (10): A photomicrograph of a section of liver of (Group 2) tramadol treated rat showing; dilated congested Portal Vein (P.V) and mild dilated Hepatic Artery (H.A) and bile duct (B). (H \& E X400). 


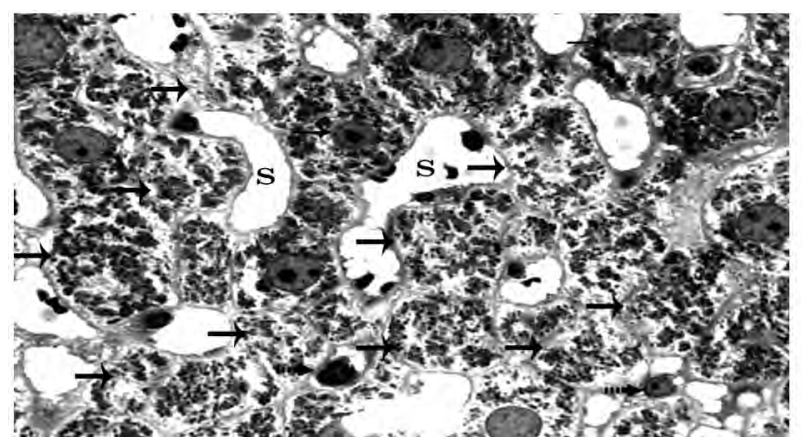

Fig. (11): A photomicrograph of semithin section in liver of (Group 2) tramadol treated rat showing; marked dilatation of some blood Sinusoids (S), absence of nuclei and vacuolated cytoplasm of some hepatocytes (thick arrows), some nuclei appeared shrinked and dark stained (thin arrows), some von kupffer cells were enlarged (dotted arrows). (Toluidine blue X 1000).

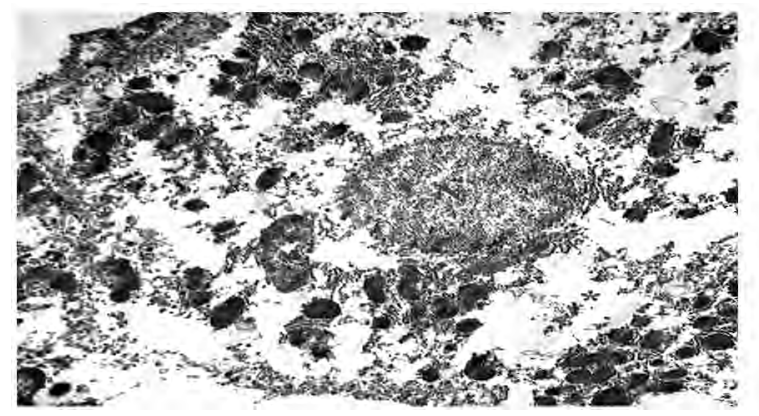

Fig. (13): An electron micrograph of a hepatocyte in liver of (Group 2) tramadol treated rat showing; a marked shrinked Nucleus $(\mathrm{N})$, decreased number of mitochondria $(\mathrm{M})$ and rarification of cytoplasm $(*)$. (X4800).

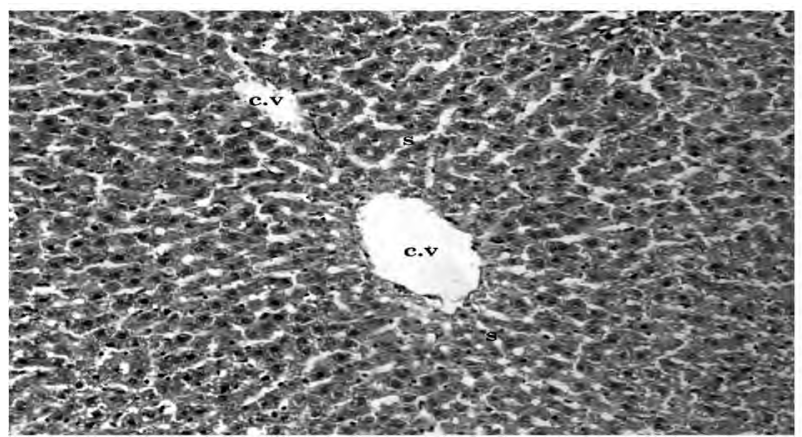

Fig. (15): A photomicrograph of a section of liver of (Group 3 ) tramadol-curcumin treated rat showing; mild dilated Central Vein (C.V), regular pattern of hepatocytes and normal blood Sinusoids (S). (H \& E X200).

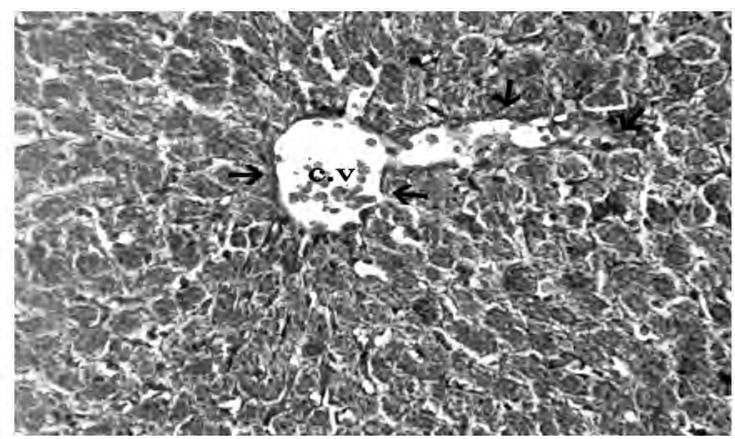

Fig. (12): A photomicrograph of a section of liver of (Group 2) tramadol treated rat showing; increased distribution of collagen fibers around the Central Vein (C.V) (arrows). (Masson's trichrome X400).

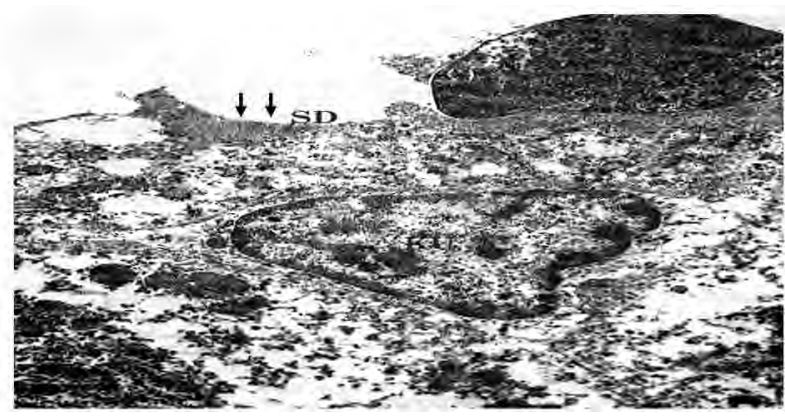

Fig. (14): An electron micrograph of blood sinusoid in liver of (Group 2) tramadol treated rat showing; enlarged Von Kupffer cell (KU) and Space of Disse (SD) with abscent fenestrations (arrows). (X7200).

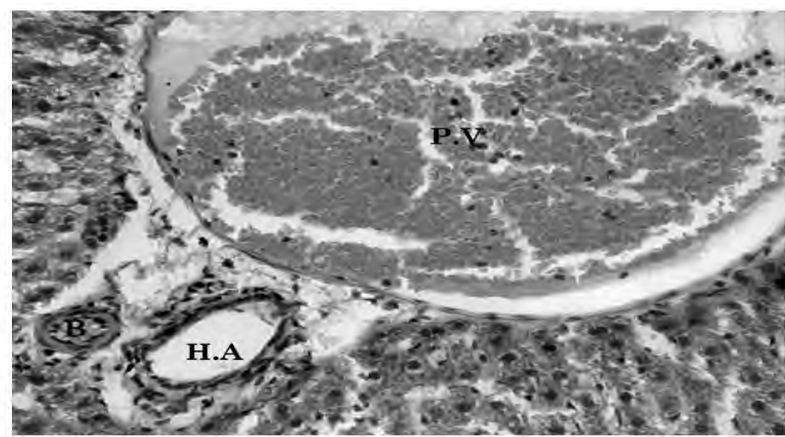

Fig. (16): A photomicrograph of a section of liver of (Group 3) tramadol-curcumin treated rat showing; marked dilated congested Portal Vein (P.V), normal Hepatic Artery (H.A) and bile duct (B). (H \& E X400). 


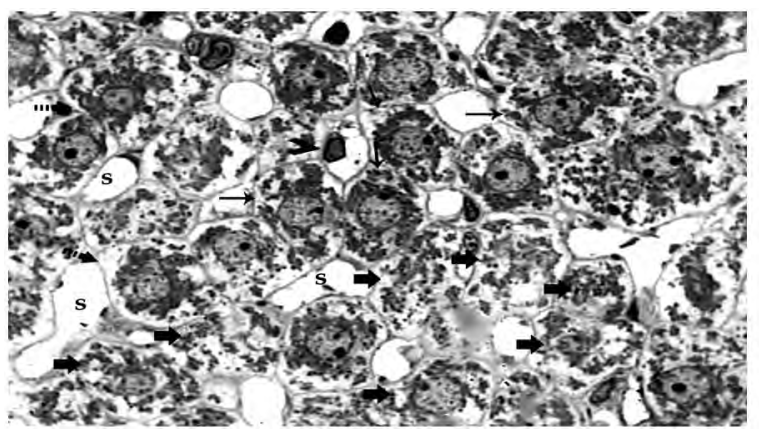

Fig. (17): A photomicrograph of semithin section in liver of (Group 3) tramadol-curcumin treated rat showing; absence of nuclei of some hepatocytes with vacuolated cytoplasm (thick arrows). Other hepatocytes had shrunken nuclei (dotted arrows). Von kupffer cell appeared enlarged (arrow head). Some hepatoctes appeared with normal nuclei and cytoplasm (thin arrows). Blood Sinusoids (S) appeared normal. (Toluidine blue X1000).

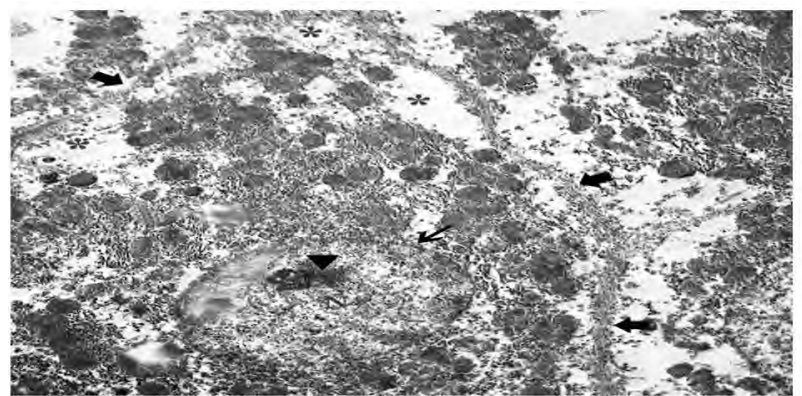

Fig. (19): An electron micrograph of a hepatocyte in liver of (Group 3) tramadol-curcumin treated rat showing; well defined cell border (thick arrows) a mild shrunken Nucleus (N) with well defined border (thin arrow), prominent nucleolus (arrow head), multiple Mitochondria (M) and rarified cytoplasm (*). (X4800).

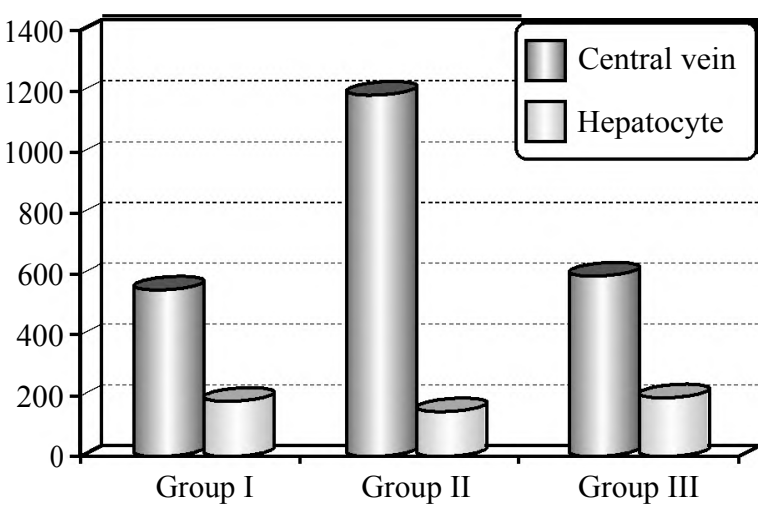

Diagram (1): Showing the mean diameter (in pixels) of central vein and hepatocyte in control and experimental groups.

\section{Discussion}

The results of the present study about the effects of tramadol on the hepatic tissue were confirmed by a previous study which reported that tramadol had toxic effects on the liver. Tramadol treatment

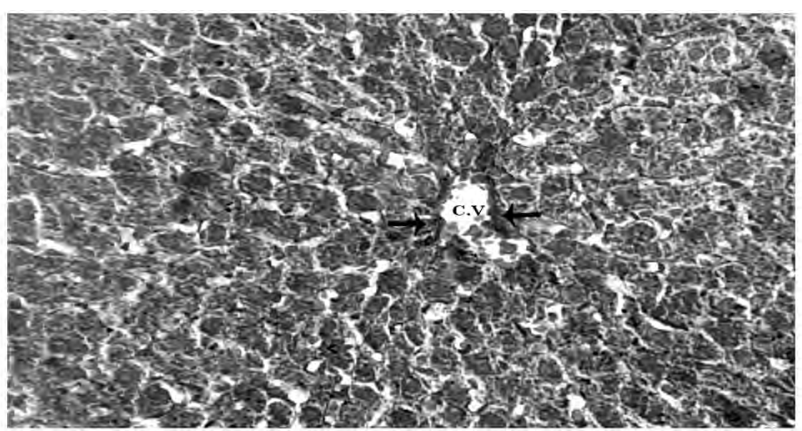

Fig. (18): A photomicrograph of a section of liver of (Group 3) tramadol-curcumin treated rat showing; minimal distribution of collagen fibers around the Central Vein (C.V) (arrows). (Masson's trichrome X400).

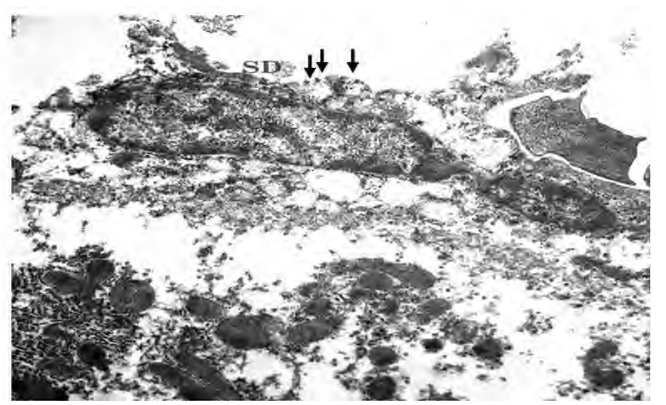

Fig. (20): An electron micrograph of blood sinusoid in liver of (Group 3) tramadol-curcumin treated rat showing small stellate cell (ST), enlarged Von Kupffer cell (KU) and Space of Disse (SD) with fenestrations (arrows). (X7200).

caused congested central vein, vacuolated hepatocytes' cytoplasm which indicated hydropic degeneration, and some hepatocytes showed apoptotic nuclei. The portal area showed dense inflammatory reaction with congestion in the portal vein. There was an increase in the collagen fibers in the hepatic tissue [13]

Tramadol when given in different doses caused histological changes ranged from central vein dilatation and vacuolation of cytoplasm (in dose of $12.5 \mathrm{mg} / \mathrm{kg}$ ) to necrosis, hemorrhage and cytolysis (in a dose of $25 \mathrm{mg} / \mathrm{kg}$ ) to complete cell membrane degeneration of hepatocytes (in the maximum dose $50 \mathrm{mg} / \mathrm{kg}$ ) [11]

These effects were explained by the ability of opioids to injure the hepatocytes by increasing the oxidative damage of DNA, protein and lipid. Opioids also decrease the levels of antioxidants such as superoxide dismutase, catalase and GSH perox- 
idase and the ratio of GSH/oxidised GSH, that oxidative damage of biomolecules and hepatotoxicity can be prevented by exogenous antioxidants [14]

The results were also in agreement with a previous study which found that hepatocytes had shrunken nuclei, swollen mitochondria, many lysosomes and autophagic vacuoles. Activated Ito (stellate cells) and Von Kupffer cells were also demonstrated [15].

The results of administration of tramadol and curcumin in the present study were confirmed by a previous study which proved the antioxidant and anti-inflammatory effects of curcumin on hepatic tissue damaged by sepsis. Sepsis caused severe sinusoidal dilatation, and congestion, damaged hepatocytes with cytoplasmic vacuoles and activated Kupffer cells. Curcumin group showed mild sinusoidal dilatation and congestion. Majority of hepatocytes appeared normal [16].

Curcumin has biological and pharmacological properties such as antioxidant, anti-inflammatory, antifungal, antibacterial, anti-ischemic, antitumor and anticancer actions. The molecular mechanisms of curcumin are its ability to suppress lipid perioxidation and oxidative stress in several demonstrated tissues. It also has inhibitory activity against nuclear factor (NF)- $\mathrm{Kb}$ that regulates different proinflammatory and prorofibrotic cytokines [17]

A previous study showed that curcumin had the ability to restore the activity of the antioxidant enzymes (SOD (Superoxide Dismutase), catalase, and GSH peroxidase) and decreased the hepatic MDA (malondialdehyde) level. Antioxidant defense mechanism is affected by reactive oxygen species generated from lipid perioxidation initiated by drug or hepatotoxin. The antioxidant mechanism of curcumin is due to its specific conjugated structure comprising two methylated phenols and an enol form of (3-diketone. Curcumin acts as a chain breaking antioxidant and trapping of free radicles due to this structure [18].

On the other hand curcumin showed no effect on the liver by light and electron microscope in ischemia/reperfusion injury following blood flow arrest. Ischemia caused loss of intercellular borders, cytoplasmic hypereosinophilic changes, nuclear picnosis, necrotic hepatocytes, and hemorrhage in some areas. Curcumin did not improve these changes. Antioxidant activity did not change with curcumin administration [19]

\section{Conclusion:}

- Tramadol had a chronic toxic effect on liver and caused dilatation in the central vein and blood sinusoids and degeneration of hepatocytes.

- Administration of curcumin to tramadol partially improved the effects caused by tramadol and decreased degeneration of hepatocytes.

\section{Recommendations:}

More researches on the antioxidant effect of curcumin on different types of tissues and against different toxic drugs are recommended.

\section{References}

1- LAVASANI H., SHEIKHOLESLAMI B., ARDAKANI Y., ABDOLLAHI M., HAKEMI L. and ROUINI M.R.: Study of the pharmacokinetic changes of Tramadol in diabetic rats. DARU Journal of Pharmaceutical Sciences; (21), pp: 17-25, 2013.

2- MODI H., MAZUMDAR B. and BHATT J.: Study of interaction of tramadol with amlodipine in mice. Indian Journal of Pharmacology; (45), pp: 76-9, 2013.

3- EL-SAYED A.Y., MOHAMED K.M., NASSER A.Y., BUTTON G., and HOLT D.W.: Simultaneous determination of tramadol, O-desmethyltramadol and N-desmethyltramadol in human urine by gas chromatographymass spectrometry. Journal of Chromatography B (926), pp: 9-15, 2013.

4- SCOTT L.J. and PERRY C.M.: Tramadol. A review of its use in perioperative pain. Adis. Drug Evaluation Journal; (60), pp: 139-76, 2000.

5- EASSA B.I. and EL-SHAZLY M.A.: Safety and efficacy of Tramadol Hydrochloride on treatment of premature ejaculation. Asian Journal of Andrology (15); pp: 13842, 2013.

6- FOWLER D.: Tramadol for the treatment of functional gastrointestinal disorders. PUB: NO.US8716347 B2, 2014.

7- BENZIE I. and WACHTEL-GALOR S.: Herbal medicine: Biomolecular and Clinical aspects. 2 nd Edition. CRC Press, pp: 120-9, 2011

8- TIRKEY N., KAUR G., VIJ G. and CHOPRA K.: Curcumin, a diferuloylmethane, attenuates cyclosporine-induced renal dysfunction and oxidative stress in rat kidneys. Biomedical Central pharmacology, pp: 5: 15, 2005.

9- PRASAD S., TYAGI A.K. and AGGARWAL B.B.: Recent Developments in Delivery, Bioavailability, Absorption and Metabolism of Curcumin: The Golden Pigment from Golden Spice. Official Journal of Korean Cancer Association (46), pp: 2-18, 2014.

10- MAHFOUZ M.M., ZHOU Q. and KUMMEROW F.A.: Effect of curcumin on LDL oxidation in vitro, and lipid peroxidation and antioxidant enzymes in cholesterol fed rabbits. International Journal of Vitamin and Nutrition Research (81); pp: 378-91, 2011.

11- SALEEM R., IQBAL R., ABBAS M.N., ZAHRA A., IQBAL J. and ANSARI M.S.: Effects of Tramadol on Histopathological and Biochemical Parameters in Mice 
(Mus musculus) Model. Global Journal of Pharmacology (8), pp: 14-9, 2014.

12- KALPANA C. and MENON V.P.: Modulatory effects of curcumin on lipid perioxidation and antioxidant status during nicotine-induced toxicity. Pol. Journal of Pharmacology (56), pp: 581-6, 2004.

13-AWADALLA E.A. and SALAH-ELDIN A.E.: Histopathological and molecular studies on Tramadol mediated hepato-renal toxicity in rats. Journal of Pharmacology and Biological Sciences (10), pp: 90-102, 2015.

14- ZHANG Y., ZHENG Q.H., PAN J. and ZHENG R.L.: Oxidative damage of biomolecules in mouse liver induced by morphine and protected by antioxidants. Journal of Basic \& Clinical Pharmacology and Toxicology (95), pp: 53-8, 2004.

15- OMAR N.M. and MOHAMMED M.A.: The impact of black seed oil on tramadol- induced hepatotoxicity: Immunohistochemical and ultrastructural study. Acta Histochemical Journal (119), pp: 543-54, 2017.

16- SAVCUN G.Y., ÖZKAN E., DULUNDU E., TOP-
ALOGLU U., ŞEHIRLI A.O., TOK O.E., ERCAN F. and ŞENER G.: Antioxidant and anti-inflammatory effects of curcumin against hepatorenal oxidative injury in an experimental sepsis model in rats. Ulus. Travma. Acil. Cerr. Derg. (19), pp: 507-15, 2013.

17-NABAVI S.F., NABAVI S.M., EBRAHIMZADEH M.A., ESLAMI S., JAFARI N. and MOGHADDAM H.A.: The protective effect of curcumin against sodium fluorideinduced oxidative stress in rat heart. Arch. Biological. Science Journal, 63 (3), pp: 563-9, 2011.

18- ZAIDI S.N.F. and MAHBOOB T.: Effect of curcumin supplementation on antioxidant enzymes in liver cirrhosis: Study in rats. Pakistanian Journal of Biochemical \& Molecular Biology (48), pp: 3-6, 2015.

19- OGUZ A., KAPAN M., ONDER A., KILIC E., GUMUS M., BASARALI M.K., FIRAT U., BOYUK A. and BUYUKBAS S.: The effects of curcumin on the liver and remote organs after hepatic ischemia reperfusion injury formed with pringle manoeuvre in rats. European Review for Medical and Pharmacological Sciences (17), pp: 45766, 2013.

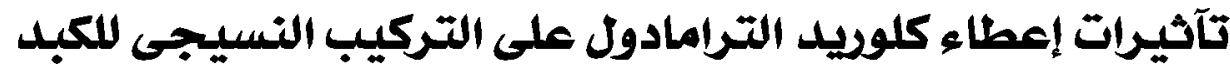

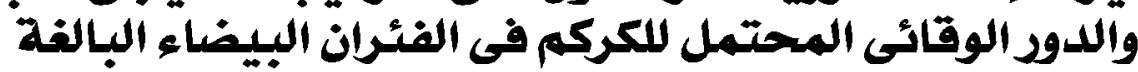

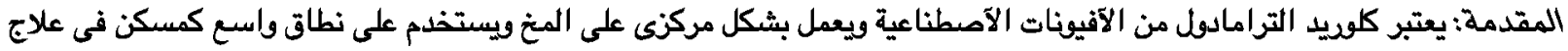

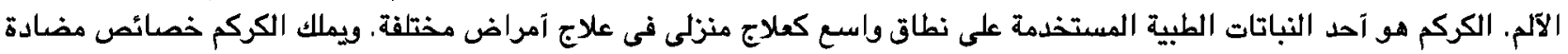 \\ لإلإلتهابات ومضادة للاككسدة. \\ الفرض من البحث: الهدف من هذه الدراسة هو الكثف عن الآثار السامة للترامادول على آنسجة الكبد ودراسة الدور الوقائى المحتمل \\ للكركم على هذه الآثار السامة. \\ الآدوات والطرق: في هذه اللدراسة تم إستخدام ثلاثين من الفئران البيضاء البالغة وتم تقسيم الميوانات إلى ثلاث مجموعات متساوية:

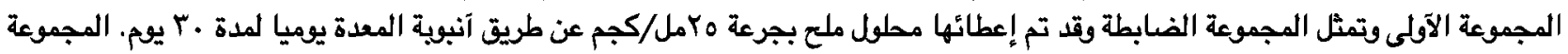

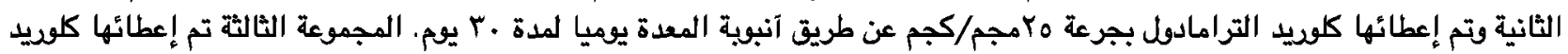

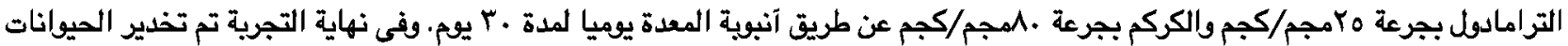

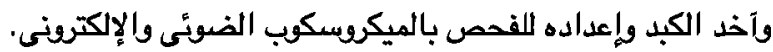 \\ النتائج: لقد سبب الترامادول إتساع فى المويد المركزى، الجيوب الدموية وتدمير فى خلايا الكبد كما إتضع بالفحص بواسطة المجهر \\ الضوئى والإلكترونى. إضـافة الكركم قامت بتصسين هذه الآثار. \\ الخلاصةة: تعبب الترامادل في فقدان النمط الطبيعى للآنسجة الكبدية مع تدمير فى بعض خلايا الكبد . إستعاد الكركم الصسدة الطبيعية \\ لآنسجة الكبد وقلل من التدمير في خلايا الكبد.
}

